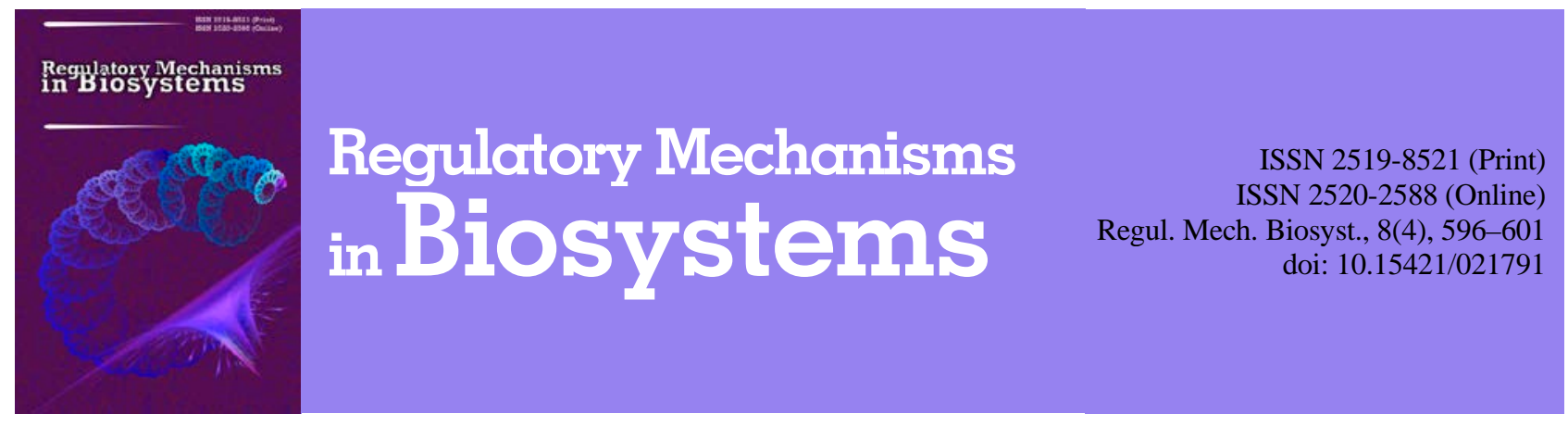

\title{
The arginase pathway of L-arginine metabolism of peripheral blood lymphocytes in patients with acne vulgaris
}

\author{
G. S. Lavryk, O. P. Korniychuk, A. S. Besedina, Z. D. Vorobets \\ Danylo Halytskyi Lviv National Medical University Department of Microbiology, Lviv, Ukraine
}

Article info

Received 29.10.2017

Received in revised form 19.11.2017

Accepted 20.11.2017

Danylo Halytsky Lviv National Medical University, Pekarska St., 69,

Lviv, 79010, Ukraine.

Tel.: +38-067-906-25-23.

E-mail: lavrykgal@gmail.com
Lavryk, G. S., Korniychuk, O. P., Besedina, A. S., \& Vorobets, Z. D. (2017). The arginase pathway of L-arginine metabolism of peripheral blood lymphocytes in patients with acne vulgaris. Regulatory Mechanisms in Biosystems, 8(4), 596-601. doi:10.15421/021791

The mechanisms of development of the inflammatory process of the pilosebaceous apparatus in patients with acne vulgaris are not fully understood, and variations in bacterial colonization are one of the key elements of the inflammatory process. Under the pathological conditions caused by pus-forming cocci which induce the production of proinflammatory cytokines, there is an increase in arginase expression. The capacity for film formation in selected strains was determined by the cultural properties (increased viscosity of the colony biomass) and by differential interference contrast microscopy using a dark field condenser and fluorescence microscopy. Arginase activity ( $\mu \mathrm{mole}$ urea/min $\bullet \mathrm{mg}$ of protein) was determined spectrophotometrically at $520 \mathrm{~nm}$ on saponin-perimabilized lymphocytes of peripheral blood by the rate of urea formation. The cultures of film-forming and planktonic forms of Staphylococcus epidermidis and Staphylococcus aureus were isolated from purulent pustules of 44 patients, aged 18-30. 63.6\% of clinical strains of film-forming staphylococci were isolated, out of which 15 strains (53.6\%) were S. aureus and 13 strains (46.4\%) S. epidermidias. It was found that the arginase activity in patients (film-forming S. aureus) was significantly higher than in practically healthy donors (control) and was equal to $0.262 \pm 0.006$ and $0.279 \pm 0.005$ (planktonic form of $S$. aureus) versus $0.087 \pm$ $0.009 \mu$ mole urea / min.mg of protein in the control. The arginase activity in patients (film-forming S. epidermidis) was significantly higher than in practically healthy donors and was equal to $0.281 \pm 0.009$ and $0.297 \pm 0.006$ (planktonic form of S. epidermidis) versus $0.087 \pm 0.009 \mu \mathrm{mol}$ urea / $\mathrm{min} \cdot \mathrm{mg}$ of protein in the control. After the auto-vaccine therapy and the administration of the probiotic Lacidofil (Institut Rosell Inc., Canada), enzyme activity decreased significantly in both experiments, however it had not attained control levels. The enzyme activity decreased through the administration of a vaccine, which in turn has an immunomodulating and immunostimulating effect. In addition, comparing the data of the arginase activity after treatment in patients with S. epidermidis, there was a slight decrease in the enzyme activity. This result is probably due to the formed tolerance of the immune system to commensal microorganisms. It was found that all patients had a moderate dysbiosis, which was accompanied by a deficiency of the main normal symbionts of the intestine. After treatment, all patients experienced significant improvementst in the microbiocenosis of the intestine in the direction of normalization of parameters and improvement of the skin condition. Increase in arginase activity in patients with acne vulgaris indicates the competition of this enzyme with NO-synthases for the substrate L-arginine and the alteration of physiological reactions in the organism caused by staphylococci which induce the phagocytic response and the cytokines production of the humoral system.

Keywords: acne; arginase; Staphylococcus aureus; Staphylococcus epidermidis

\section{Неокисний шлях метаболізму L-аргініну лімфоцитів периферичної крові у хворих на acne vulgaris}

\author{
Г .С. Лаврик, О. П. Корнійчук, А. С. Беседіна, 3. Д. Воробець
}

Львівський наиіональний медичний університет імені Данила Галицького, Львів, Україна

Проведено аналіз джерел літератури, що стосуються ролі стафілококів в етіології acne vulgaris. Згідно із сучасними уявленнями про патогенез вугрової хвороби, остання - мультифакторне захворювання. Один із їі чинників - проліферація умовно-патогенної мікрофлори шкіри, що сприяс вивільненню медіаторів запалення та розвитку запального процесу. Аргіназна активність лімфоцитів - важливий маркер, що вказує на гуморальну відповідь із боку імунної системи на антиген. Досліджено зміни ензиматичної активності аргінази лімфоцитів периферичної крові у хворих на вугрову хворобу, в яких захворювання супроводжувалося висіванням біоплівкових і планктонних форм стафілококів. Обстежено 44 хворих віком від 18-30 років з acne vulgaris та визначено аргіназну активність до та після лікування. Виявлено значне зростання аргінази лімфоцитів крові у хворих на вугрову хворобу, спричинених біоплівковими та планктонними формами стафілококів. Установлено помірний дисбіоз, який супроводжувався дефіцитом основних нормосимбіонтів кишечника. Після курсу лікування 
автостафілококовою вакциною та біопрепаратом «Лацидофіл» (Institut Rosell Inc., Канада) значно знизилась активність ензиму, спостерігали тенденцію до нормалізації показників нормофлори кишечника та поліпшення стану шкіри (зникли почервоніння, набряк, запальні елементи).

Ключові слова: вугрова хвороба; аргіназа; Staphylococcus aureus; Staphylococcus epidermidis

Вступ

Нині акне (acne vulgaris), або вугрова хвороба - одне $з$ найпоширеніших уражень шкіри, які у пубертатному віці проявляються тією чи іншою мірою практично у 100\% юнаків і $90 \%$ дівчат. Останніми роками спостерігається зростання рівня захворюваності на вугрову хворобу з тенденцією до збільшення частки жінок віком 25-40 років із пізніми формами акне (Colleir et al., 2008; Dumont-Wallon and Dreno, 2008; Goryachkina and Belousova, 2014). Захворювання набуває хронічного рецидивуючого перебігу з наростанням інтенсивності симптомів, стійкості до терапії (Barratt et al., 2008; Weller et al., 2008).

У розвитку вугрової хвороби не можна виділити один етіологічний чинник. Згідно 3 результатами останніх досліджень, у патогенезі акне як мультифакторного захворювання найважливіші генетична схильність, андрогено-індукована гіперсекреція шкірного сала, фолікулярна гіперкератизація, мікробна гіперколонізація з наступним розвитком запального процесу в сально-волосяних фолікулах (СВФ) і навколо них (Myadelets and Adaskevich, 2006; Elder et al., 2008; Fulton, 2009; Iinuma et al., 2009; Williams et al., 2012). Обтурація протоки СВФ і багате ліпідами шкірне сало створюють сприятливі умови для розмноження факультативних анаеробів (Propionibacterium acnes, $P$. granulosum), а також інших представників сапрофітної та умовно-патогенної мікрофлори (Staphylococcus epidermidis, Staphylococcus aureus) (Fulton, 2009). Ці мікроорганізми продукують ензим ліпазу, який розщеплює діацил- та тріацилгліцериди до гліцерину та вільних жирних кислот. Ці речовини разом з антигенами мікроорганізмів залучають із периферичної крові нейтрофіли та фагоцити, які продукують цитокіни ІЛ- $1 \alpha$, ІЛ-1 $\beta$ і ІЛ- 8 , ФНП- $\alpha$. Ці прозапальні цитокіни активують ензим циклооксигеназу, який сприяє утворенню з арахідонової кислоти головного медіатора запалення - лейкотрієн В4. Він, у свою чергу, стимулює вивільнення гідролітичних ензимів і монооксиду азоту (NO) 3 нейтрофілів, Т-лімфоцитів, моноцитів та еозинофілів, що викликає руйнування стінки сальної залози, вихід ії вмісту в дерму та розвиток запальної реакції у вигляді папуло-пустульозних і вузлувато-кістозних елементів (Jappe, 2002; Monakhov and Ivanov, 2010; Goryachkina and Belousova, 2014).

Хоча механізми хронічного запального захворювання пілосеборейного комплексу до кінця не з'ясовані, варіації бактеріальної колонізації - один з основних елементів його розвитку (Bojar and Holland, 2004). Один із патогенетичних факторів акне - проліферація нормальної мікробіоти, особливо P. aсnеs. Спостерігається високий ступінь кореляції гіперпродукції шкірного сала 3 кількістю $P$. acnes, що визначається створенням оптимального анаеробного середовища для їх росту. Проте чіткого зв'язку між кількістю $P$. acnes і ступенем тяжкості захворювання не встановлено, а також не визначено того порогу кількості P. acnes, що відокремлює здорову та проблемну шкіру, уражену акне (Yoshimoto et al., 1998).

Окрім P. acnes, розвитку запального процесу сприяють бактерії, що персистують на поверхні шкіри: S. aureus, Streptococcus pyogenes, S. epidermidis, Haemophilus spp., Escherichia coli тощо. Навколо ураженого фолікула формується зона запалення, до якої мігрують нейтрофіли, макрофаги, Т-лімфоцити та інші імунокомпетентні клітини. $P$. acnes підтримує запальний процес шляхом активації специфічних Тoll-подібних рецепторів (TLR) на мембранах імунокомпетентних клітин і себоцитів (Kalyujna et al., 2014). У хворих на акне виявили значну експресію TLR-2 на перифолікулярних і перибульбарних макрофагах, окрім того показано in vivo та in vitro, що існує позитивна кореляція між ступенем ураження акне та концентрацією клітин, що несуть на собі TLR-2 і TLR-4. Продукція цитокінів IL-
6, IL-8 та IL-12 прямо залежить від взаємодії P. acnes i TLRрецепторів (Kang et al., 2006; Lai and Gallo, 2008; Miller, 2008; Valins et al., 2010).

Однак TLR-2 - специфічний рецептор і для $S$. aureus. Mempel et al. (2003) показали стимуляцію кератиноцитів патогеном S. aureus, що викликало транслокацію ядерного транскрипційного фактора NF-kB, подальше підвищення продукції IL-8 i iNOS i швидку протективну відповідь. Ця запальна реакція залежна від TLR-2 (Mempel et al., 2003). Таким чином, доведено, що стимуляція молекулярними патернами різних мікроорганізмів (пептидоглікан, ліпопептиди) TLR-2 i TLR4 наростає, i як наслідок розвивається дисфункція в системі TLRs, що частково пояснює хронізацію та рецидивування вугрової хвороби в результаті порушення як вродженого, так і адаптивного імунітету (Sorokina, 2012).

Критика концепції, що розглядає P. acnes як єдину бактерію - «винуватця» запальних явищ за акне, грунтується не тільки на невдачах виявлення P. acnes у фолікулах і різних елементах акне (Zouboulis, 2009). Виявлено, що до $28 \%$ запальних елементів акне можуть розвиватися de поvо, минаючи стадію комедонів, що дає більше підстав для взаємозв'язку запалення та присутності бактерій на поверхні шкіри (Do et al., 2008). Крім того, утворення біоплівок стафілококами викликає обтурацію потових залоз, що має значення у патогенезі атопічного дерматиту (Allen et al., 2014), і не можна виключити аналогічного впливу за акне (Burceva et al., 2013). Виробляючи дельтатоксин, що індукує дегрануляцію опасистих клітин, S. aureus може запускати місцеве запалення, стимулюючи як вроджений, так і адаптивний імунітет (Nakamura et al., 2013).

Адекватна модель для вивчення патологічних змін в організмі - лімфоцити периферичної крові, які знаходяться переважно в одній фазі клітинного циклу $\left(\mathrm{G}_{0}\right)$, у звичайних умовах не діляться, легко піддаються культивуванню (Buchinska et al., 2002). Внутрішньоклітинний метаболізм лімфоцитів грунтується на фізіологічно та біохімічно закріпленій здатності цих клітин швидко реагувати на будь-які порушення гомеостазу в організмі, а модуляція активності ензимів у лімфоцитах настає значно раніше, ніж змінюються їх морфологічні та біохімічні показники (Lugovskoy, 2002). Це дає змогу використовувати лімфоцити як «метаболічне дзеркало організму» (Yakubets et al., 2013).

Мета дослідження - оцінити активність аргінази лімфоцитів осіб з асnе vulgaris, в яких захворювання супроводжувалося висіванням біоплівкових і планктонних форм стафілококів. Активність ензиму визначали до та після лікування.

\section{Матеріал і методи досліджень}

Досліджено 44 хворі віком від 18-30 років, із гнійних пустул яких ізольовано культури плівкотвірних і планктонних форм S. aureus та $S$. epidermidis. Виділення та ідентифікацію стафілококів проводили з використанням стандартних середовищ у лабораторії кафедри мікробіології ЛНМУ імені Данила Галицького відповідно до наказу (Birger, 1982; Vos et al., 2008). Референтний штам S. aureus ATCC 25923 (F-49) отримано з музейної колекції бактеріологічної лабораторії Львівського обласного лабораторного центру для контрольного показника біоплівки.

Здатність до плівкоутворення у відібраних штамів визначено за культуральними властивостями (підвищена в'язкість біомаси колонії) та за допомогою диференціальної інтерференційно-контрастної мікроскопії (DIC) з використанням конденсора темного поля та флуоресцентної мікроскопії.

Для цього біоплівки клінічних і стандартних ізолятів вирощували на стерильних покривних скельцях на дні пластикових чашок (Ø 50 мм). У кожну чашку вносили по 4 мл поживного бульйону («Фармактив», Україна) та по 10 мкл культури мутністю $1,5 \times 10^{9}$ кл./мл (що відповідає 5 од. за стандартом 
McFarland), так, щоб суспензія рівномірно розподілилась на дні чашки. Чашки інкубували в термостаті 48 годин за температури $37^{\circ} \mathrm{C}$. Через 48 годин вміст чашок відбирали, щоб не зруйнувати сформовану біоплівку, та тричі відмивали дистильованою водою. Виявляли життєздатних бактерій подвійним прижиттєвим забарвленням за допомогою флуоресцентних барвників, а саме Hoechst-33258, який вільно проникає крізь клітинні мембрани, зв'язується у ядрі з ДНК на зовнішньому боці спіралі, зумовлюючи при цьому флуоресценцію (Hawley and Hawley, 2004). Пропідіум йодид проникає лише в некротичні клітини та зв'язується 3 ДНК, зумовлюючи флуоресценцію в червоній ділянці спектра (Schlegel and Fullekrug, 2002; Krysko et al., 2008).

Мікроскопію бактеріальних біоплівок проводили за допомогою мікроскопа Nikon Eclipse (об’єктив 63x/1.4NA) методом інтерференційної (диференційно-інтерференційний контраст DIC) мікроскопії з використанням конденсора темного поля та флуоресцентної мікроскопії.

Лімфоцити виділяли зі свіжоотриманої периферичної гепаринізованої крові пацієнтів (до та після лікування) та в осіб групи контролю у градієнті густини фікол-тріумбрасту ( $\rho=$ $\left.1,08 \Gamma / \mathrm{cm}^{3}\right)$. Групу контролю становили практично здорові особи $(\mathrm{n}=9)$. Усім хворим проводили курс вакцинотерапії автостафілококовою вакциною та пробіотичним препаратом «Лацидофіл» (Institut Rosell Inc., Канада).

Активність аргінази визначали на пермеабілізованих сапоніном лімфоцитах периферичної крові за швидкістю утворення сечовини. Ї̈̈ вміст вимірювали за допомогою діагностичного набору фірми «Сімко» (Україна), згідно з інструкцією. Зразки спектрофотометрували за 520 нм проти контрольних проб, які містили дистильовану воду. Активність аргінази виражали в мікромолях сечовини, що утворилася протягом однієї хвилини у розрахунку на мг протеїну.

Визначали середнє арифметичне значення (х), похибку середнього арифметичного (m). Для оцінювання ступеня вірогідності результатів дослідження застосовували ANOVA. Bipoгідність різниці вважали статистично достовірною за $\mathrm{P}<0,05$.

\section{Результати та їх обговорення}

Із гнійних пустул хворих $(\mathrm{n}=44)$ виділено 28 штамів (63,6\%) плівкотвірних стафілококів, із них 15 штамів (53,6\%) складає S. aureus i $13(46,4 \%)$ - S. epidermidis. Активність аргінази лімфоцитів крові у хворих (плівкотвірний $S$. aureus) була достовірно вищою за відповідний показник практично здорових осіб і становила $0,262 \pm 0,006$ та $0,279 \pm 0,005$ (планктонна форма $S$. aureus) проти $0,087 \pm 0,009$ мкмоль сечовини/хв·мГ протеїну в контролі (рис. 1).

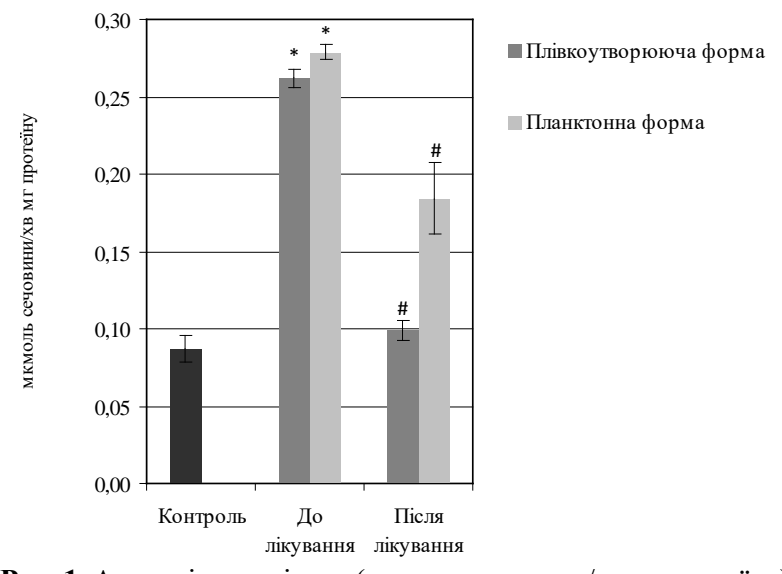

Рис. 1. Активність аргінази (мкмоль сечовини/хв·мг протеїну) лімфоцитів крові у паціснтів, хворих на acne vulgaris, спричинену S. aureus (плівкотвірна форма, $\mathrm{n}=15$, планктонна форма, $\mathrm{n}=9$ ): * $-\mathrm{P}<0,001-$ зміни достовірні щодо величин в осіб групи контролю (практично здорові донори); \# - $\mathrm{P}<0,001$ зміни достовірні щодо величин у пацієнтів до лікування
Після проведенного курсу лікування активність ензиму значно знизилася до $0,099 \pm 0,006$ (плівкотвірний S. aureus) (P $<$ $0,001)$ та до 0,184 $\pm 0,023$ (планктонна форма S. aureus) (P< $0,001)$ мкмоль сечовини/хв·мг протеїну. Активність аргінази у хворих (плівкотвірний S. epidermidis) була достовірно вищою за відповідний показник контрольних осіб: 0,281 $\pm 0,009$ та 0,297 \pm 0,006 (планктонна форма S. epidermidis) проти 0,087 \pm 0,009 мкмоль сечовини/хв·мг протеїну в контролі (рис. 2).

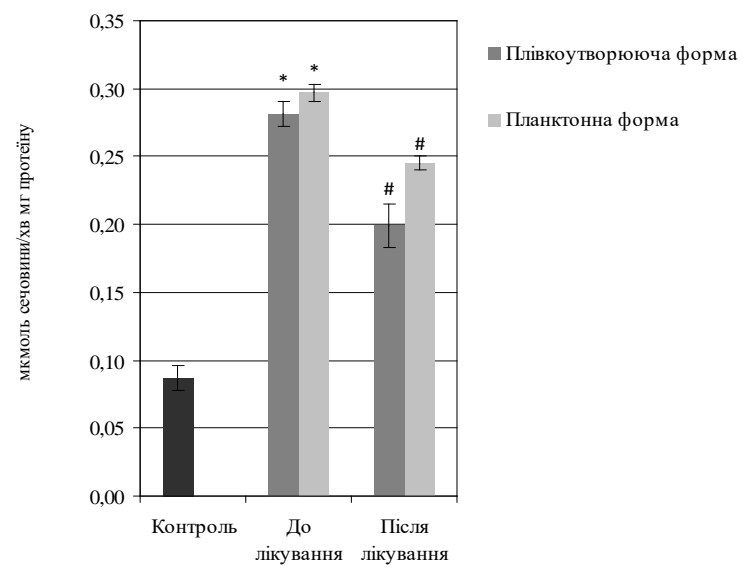

Рис. 2. Активність аргінази (мкмоль сечовини/хв·мг протеїну) лімфоцитів крові у пацієнтів, хворих на acne vulgaris, спричинену S. epidermidis (плівкотвірна форма, $\mathrm{n}=13$, планктонна форма, $\mathrm{n}=7$ ): * $-\mathrm{P}<0,001$ - зміни достовірні щодо величин в осіб групи контролю (практично здорові донори); \# - $<$ 0,001 - зміни достовірні щодо величин у пацієнтів до лікування

Після курсу лікування активність ензиму значно знизилася до 0,199 $\pm 0,016$ (плівкотвірний S. epidermidis) $(\mathrm{P}<0,001)$ та до $0,245 \pm 0,005$ мкмоль сечовини/хв·мГ протеїну (планктонна форма S. epidermidis $)(\mathrm{P}<0,001)$.

Порівнюючи показники (рис. 1,2$)$ активності аргінази до та після лікування, спостерігали незначне зниження рівня експресії ензиму після лікування: в 1,4 раза (плівкотвірний S. epidermidis) проти 2,5 раза (плівкотвірний S. aureus).

Під час досліджень установлено дефіцит основних нормосимбіонтів кишечника (зниження кількісних рівнів біфідобактерій і лактобактерій до $10^{6-7}$ КУО/мл). У $65 \%$ пацієнтів виявлено зниження E. coli до $5 \times 10^{7} \mathrm{KУО/мл.} \mathrm{За} \mathrm{наявності} \mathrm{у}$ хворих закрепів зростала кількість гемолітичних форм кишкової палички.

\section{Обговорення}

Гуморальні протизапальні цитокіни IL-4, IL-10, IL-13 і TGF- $\beta$ впливають на експресію аргінази, локалізованої як у цитозолі, так і в мітохондріях (Munder et al., 2005; Ochoa et al., 2007; Peretiatko and Sybirna, 2009) і яка конкурує з NO-синтазами за L-аргінін. Високий рівень експресії аргінази свідчить про гуморальну відповідь із боку імунної системи на антиген (Klasen et al., 2001; Barksdale et al., 2004; Holan et al., 2006). Під час досліджень виявлено значне зростання експресії аргінази у хворих на вугрову хворобу. Після лікування встановлено достовірне зниження активності аргінази, проте вона не досягла рівня контролю.

Аргіназа експресується не тільки у клітинах людського організму, а й у бактеріальних (таких, як Pseudomonas aeruginosa та S. aureus). Золотистий стафілокок - патоген, який несе власну аргіназу, здатний моделювати аргіназу господаря. Тому не виключений внесок бактеріальної аргінази до загальної активності аргінази (Grasemann et al., 2005).

Останніми роками описано низку механізмів, за допомогою яких стафілококи протистоять агресивному впливу макро- 
організму та виживають на поверхні шкіри: стафілоксантини, системи розпізнавання антимікробних пептидів (ApsRS i GraRS), аргініновий катаболічний мобільний елемент (ACME), кардіоліпін та ін. (Coates et al., 2014). ACME кодує декілька генів, включаючи другу копію аргінін деімінази - ферменту, здатного перетворювати аргінін на орнітин. Оскільки аргінін - амінокислота в роговому шарі шкіри, яка потенційно може використовуватись для утворення оксиду азоту або для підкислення $\mathrm{pH}$ шкіри, виснаження пулу аргініну може оптимізувати умови росту для стафілококів (Otto, 2010). АCME був у штаму $S$. aureus USA300 горизонтально перенесений від $S$. epidermidis. Майже половина виділених $S$. epidermidis містить ACME, що закодований у speG (Diep et al., 2006; Miragaia et al., 2009). Цей шлях може бути одним із важливих механізмів уникнення стафілококами імунної відповіді хазяїна та переваги для росту на шкірі (Das et al., 2010; Scharschmidt and Fischbach, 2013). Heзважаючи на наявність великої кількості доказів про метаболізм аргініну та його роль в імунології, вирішальний вибір шляху метаболізму аргініну патогенними мікроорганізмами залишається до кінця не з'ясованим (Das et al., 2010).

У проведеному дослідженні виділення стафілококів із гнійних пустул за акне доводить, що стафілококи відіграють важливу роль у розвитку запального процесу на шкірі. Результати показують, що концентрація стафілококів зростає у процесі наростання клінічних проявів акне (Burceva et al., 2013; Dreno et al., 2017).

Отримане у нашому експерименті незначне зниження експресії ензиму у хворих, із пустул яких виділено S. epidermidis, показує, що сила імунної відповіді менш виражена порівняно 3 реагуванням на активність золотистого стафілокока, оскільки епідермальний стафілокок - облігатний представник нормобіоценозу шкіри.

Формування адаптивних імунних реакцій на коменсали відбувається в неонатальний період (Nagao and Segre, 2015). В умовах оптимального функціонування імунної системи альянс із мікробіотою допускає індукцію захисних реакцій на патогени та підтримання регуляторних шляхів, пов’язаних зі збереженням толерантності до коменсалів. Поза тим, вони спричиняють серйозні інфекції в осіб в умовах імуносупресії та часто стають причиною нозокоміальних інфекцій, хронічних виразок діабетичних хворих, а також показниками коагулазо-негативних стафілококових інфекцій у медичних закладах (Grice and Segre, 2012; Sanford and Gallo, 2013; Belkaid and Hand, 2014). Це може бути частково зумовлено екзополімерами S. epidermidis, які захищають їх від розпізнавання антитілами.
Крім того, еволюційний розвиток імунної системи передбачав уникнення надмірного реагування на коменсальні бактерії (Otto, 2009).

У загостренні ранніх і пізніх акне особливу роль відіграє стійке специфічне порушення мікробіоценозу кишечника, яке зумовлює зміни складу шкірного сала зі зниженням його бактерицидних властивостей. У мікробіоті кишечника у пацієнтів 3 акне різко зменшується кількість Lactobacillus, підвищується активність S. aureus, зростає роль гемолітичних форм E. coli (Averina and Salamova, 2014; Clark et al., 2017), що спричинює загострення ранніх та пізніх акне. На основі наших досліджень установлено, що в усіх хворих спостерігався помірний дисбіоз, що збігається з даними цих досліджень.

Незважаючи на достатньо добре вивчені механізми розвитку вугрової хвороби та розроблені уніфіковані протоколи лікування, не втрачають актуальності питання підвищення ефективності терапії акне, досягнення швидшого регресу елементів акне, стійкої та тривалої ремісії, естетичного результату (Protsenko et al., 2015). 3 огляду на викладене вище, доцільно використовувати препарати, що нормалізують мікрофлору кишечника та підвищують імунітет шкіри (Volkova et al., 2001; Bowe, 2013; Korolenko, 2016). У зв’язку із цим усім пацієнтам проведено курс вакцинотерапії автостафілококовою вакциною та пробіотичним препаратом «Лацидофіл» (Institut Rosell Inc., Канада). Після корекції мікрофлори травного тракту пробіотичними препаратами відбулась нормалізація рівня показників основних нормосимбіонтів.

Доведено ефективність використання лактобактерій і біфідобактерій для лікування шкірних захворюваннях у вигляді препаратів місцевого застосування (Valdez et al., 2005; Peral et al., 2009; Gueniche et al., 2010; Peral et al., 2010; Lavryk et al., 2017). Як продемонстровано, пробіотичні штами лактобактерій можуть пригнічувати прилипання шкірного патогена $S$. aureus до кератиноцитів людини (Prince et al., 2012) та попереджувати їх розмноження. Пероральні пробіотики можуть регулювати вивільнення запальних цитокінів у шкірі (Hacini-Rachinel et al., 2009) та специфічно знижувати IL-1 $\alpha$ (Cazzola et al., 2010). Підвищуючи проліферацію Т- і В-лімфоцитів та синтез IgA, пробіотичні препарати відновлюють місцевий імунітет. За умов нормалізації мікробного пейзажу стабілізується та підтримується імунна функція кишечника, що сприяє усуненню запальних симптомів акне та збільшує тривалість ремісії дерматозу (Protsenko et al., 2015). Після лікування практично зникли вугрові висипання, почервоніння та набряк навколо змінених запальною реакцією ділянок шкіри (рис. 3).
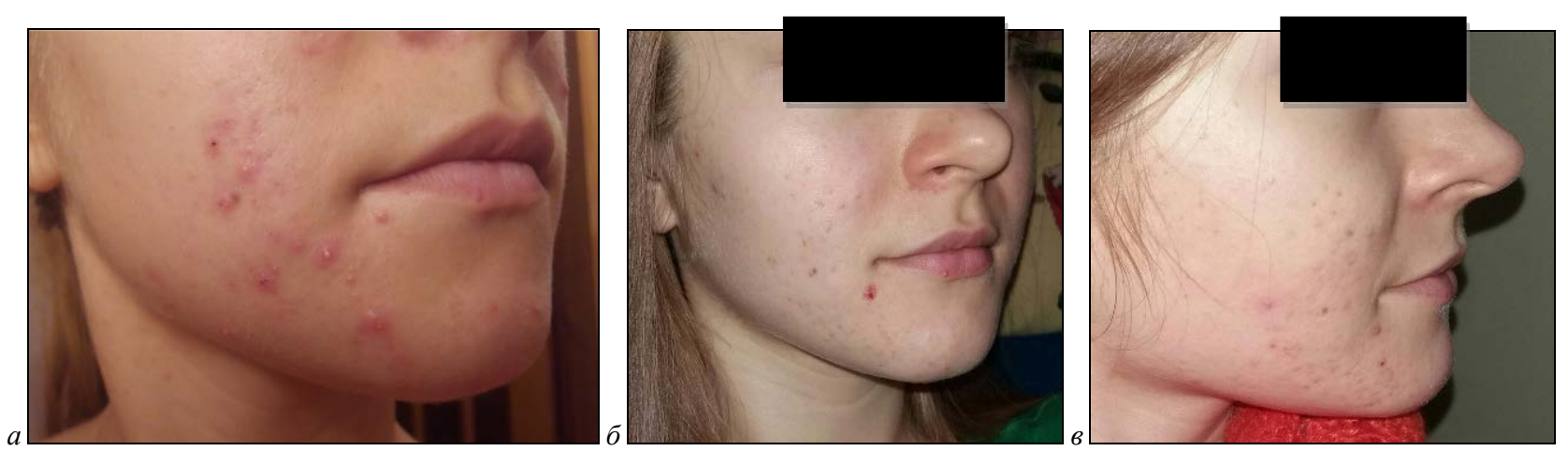

Рис. 3. Папуло-пустульозні елементи: $a$ - до лікування; 6 , в - після лікування

\section{Висновки}

Задіяння механізмів протистояння вірулентному фактору шляхом продукції прозапальних цитокінів відбувається за зростання активності ензимів. Підвищення активності аргінази у хворих на acne vulgaris свідчить про конкуренцію цього ензиму з NOсинтазами за субстрат L-аргінін та альтерацію фізіологічних реакцій в організмі, спричинену дією стафілококів, які індукують фагоцитарну реакцію та продукцію цитокінів гуморальної ланки.
Після лікування активність ензиму все ще залишається високою, хоча зафіксовано достовірні зміни у бік нормалізації активності, завдяки уведенню вакцинного препарату, які, у свою чергу, мають імуномоделювальний ефект.

Планктонна форма стафілококів, як значно менш інтенсивний подразник, індукує слабшу активацію цитокінів та ензимів, що під час проведення імуномоделювальної терапії не дає змоги розраховувати на достатньо помітний ефект. У хворих на acne vulgaris, яке супроводжувалося висіванням $S$. epidermidis, активність аргі- 
нази після лікування знизилася незначно, що може вказувати на імунну толерантність організму до «опортуністичних патогенів», що, у свою чергу, вимагає тривалішого лікування.

\section{References}

Allen, H. B., Vaze, N. D., Choi, C., Hailu, T., Tulbert, B. H., Cusack, C. A., \& Joshi, S. G. (2014). The presence and impact of biofilm-producing staphylococci in atopic dermatitis. JAMA Dermatology, 150(3), 260-265.

Averina, V. I, \& Salamova, I. V. (2014). Sovremennyj podhod k terapii vozrastnogo akne u zhenshhin [Modern approach to the treatment of age-related acne in women]. Medicinskij Sovet, 7, 62-67 (in Russian).

Barksdale, A. R., Bemard, A. C., Maley, M. E., Gellin, G. L., Keamey, P. A., Boulanger, B. R., Tsuei, B. J., \& Ochoa, J. B. (2004). Regulation of arginase expression by T-helper II cytokines and isoproterenol. Surgery, 135(5), 527-535.

Barratt, H., Hamilton, F., Car, J., Lyons, C., Layton, A., \& Majeed, A. (2009). Outcome measures in acne vulgaris: Systematic review. British Journal of Dermatology,160(1), 132-136.

Belkaid, Y., \& Hand, T. W. (2014). Role of the microbiota in immunity and inflammation. Cell, 157(1), 121-141.

Benyacoub, J., Bosco, N., Blanchard, C., Demont, A., Philippe, D., Castiel-Higounenc, I., \& Guéniche, A. (2013). Immune modulation property of Lactobacillus paracasei NCC2461 (ST11) strain and impact on skin defences. Beneficial Microbes, 5(2), 129-136.

Birger, M. I. (Ed.). (1982). Spravochnik po mikrobiologicheskim i virusologicheskim metodam issledovanija (Handbook on microbiological and virological research methods). Medicine, Moscow (in Russian)

Bojar, R. A., \& Holland, K. T. (2004). Acne and Propionibacterium acnes. Clinics in Dermatology, 22(5), 375-379.

Bowe, W. P. (2013). Probiotics in acne and rosacea. Cutis, 92(1), 6.

Buchinska, L. G., Nesina, I. P., Tkachenko, N. I., \& Polischuk, L. Z. (2002). Osoblyvosti jaderec' limfocytiv peryferychnoi’ krovi hvoryh na rak tila matky [Peculiarities of peripheral blood lymphocyte nucleoli in patients with corpus uteri cancer]. Onkologija, 4(1), 18-20 (in Ukrainian).

Burceva, G. N., Sergeev, A. Y., Arzumanyan, V. G., \& Sergeev, Y. Y. (2013). Perifollikuljarnaja mikrobiota kozhi pri akne. Chast’ I. Obshhie harakteristiki kolonizacii i rezistentnost' k sistemnym antibiotikam. [Perifollicular cutaneous microbiota in acne patients. Part I. Common patterns of colonization and resistance to systemic antimicrobials]. Immunopatologija, Allergologija, Infektologija, 2, 84-87 (in Russian).

Cazzola, M., Tompkins, T. A., \& Matera, M. G. (2010). Immunomodulatory impact of a synbiotic in Th1 and Th2 models of infection. Therapeutic Advances in Respiratory Disease, 4(5), 259-270.

Clark, A. K., Haas, K. N., \& Sivamani, R. K. (2017). Edible plants and their influence on the gut microbiome and acne. International Journal of Molecular Sciences, 18(5), 1070.

Coates, R., Moran, J., \& Horsburgh, M. J. (2014). Staphylococci: Colonizers and pathogens of human skin. Future Microbiology, 9(1), 75-91.

Collier, C. N., Harper, J. C., Cantrell, W. C., Wang, W., Foster, K. W., \& Elewski, B. E. (2008). The prevalence of acne in adults 20 years and older. Journal of the American Academy of Dermatology, 58(1), 56-59.

Das, P., Lahiri, A., Lahiri, A., \& Chakravortty, D. (2010). Modulation of the arginase pathway in the context of microbial pathogenesis: A metabolic enzyme moonlighting as an immune modulator. PLoS Pathogens, 6(6), e1000899.

Diep, B. A., Gill, S. R., Chang, R. F., Phan, T. H., Chen, J. H., Davidson, M. G., Lin, F., Lin, J., Carleton, H. A., Mongodin, E. F., Sensabaugh, G. F., \& Perdreau-Remington, F. (2006). Complete genome sequence of USA300, an epidemic clone of community-acquired meticillin-resistant Staphylococcus aureus. The Lancet, 367(9512), 731-739.

Do, T. T., Zarkhin, S., Orringer, J. S., Nemeth, S., Hamilton, T., Sachs, D. Voorhees, J. J., \& Kang, S. (2008). Computer-assisted alignment and tracking of acne lesions indicate that most inflammatory lesions arise from comedones and de novo. Journal of the American Academy of Dermatology, 58(4), 603-608.

Dreno, B., Martin, R., Moyal, D., Henley, J. B., Khammari, A., \& Seité, S. (2017). Skin microbiome and acne vulgaris: Staphylococcus, a new actor in acne. Experimental Dermatology, 26(9), 798-803.

Dumont-Wallon, G., \& Dréno, B. (2008). Specificity of acne in women older than 25 years. Presse Medicale (Paris, France: 1983), 37(4Pt1), 585-591.

Goryachkina, M. V., \& Belousova, T. A. (2014). Kombinirovannaja terapija akne u zhenshhin: Poisk optimal'nyh reshenij [Combination therapy of acne in women: Searching for optimum solutions]. Vestnik Dermatologii i Venerologii, 2, 90-95 (in Russian).

Grasemann, H., Schwiertz, R., Matthiesen, S., Racké, K., \& Ratjen, F. (2005). Increased arginase activity in cystic fibrosis airways. American Journal of Respiratory and Critical care Medicine, 172(12), 1523-1528.
Grice, E. A., \& Segre, J. A. (2012). Interaction of the microbiome with the innate immune response in chronic wounds. In: Current topics in innate immunity Vol. II. Springer, New York. pp. 55-68.

Guéniche, A., Bastien, P., Ovigne, J. M., Kermici, M., Courchay, G., Chevalier, V., Breton, L., \& Castiel-Higounenc, I. (2010). Bifidobacterium longum lysate, a new ingredient for reactive skin. Experimental Dermatology, 19(8), e1-e8.

Hacini-Rachinel, F., Gheit, H., Le Luduec, J. B., Dif, F., Nancey, S., \& Kaiserlian, D. (2009). Oral probiotic control skin inflammation by acting on both effector and regulatory T cells. PLoS One, 4(3), e4903.

Hassanzadeh, P., Bahmani, M., \& Mehrabani, D. (2008). Bacterial resistance to antibiotics in acne vulgaris: An in vitro study. Indian Journal of Dermatology, 53(3), 122.

Hawley, R., \& Hawley, T. (2004). Flow cytometry protocols. Methods in Molecular Biology, 263, 34-37.

Holán, V., Pindjáková, J., Krulová, M., Neuwirth, A., Fric, J., \& Zajícová, A. (2006). Production of nitric oxide during graft rejection is regulated by the Th1/Th2 balance, the arginase activity, and L-arginine metabolism. Transplantation, 81(12), 1708-1715.

linuma, K., Sato, T., Akimoto, N., Noguchi, N., Sasatsu, M., Nishijima, S. Kurokawa, I., \& Ito, A. (2009). Involvement of Propionibacterium acnes in the augmentation of lipogenesis in hamster sebaceous glands in vivo and in vitro. Journal of Investigative Dermatology, 129(9), 2113-2119.

Jappe, U., Ingham, E., Henwood, J., \& Holland, K. T. (2002). Propionibacterium acnes and inflammation in acne; $P$. acnes has T-cell mitogenic activity. British Journal of Dermatology, 146(2), 202-209.

Jung, G. W., Tse, J. E., Guiha, I., \& Rao, J. (2013). Prospective, randomized, open-label trial comparing the safety, efficacy, and tolerability of an acne treatment regimen with and without a probiotic supplement and minocycline in subjects with mild to moderate acne. Journal of Cutaneous Medicine and Surgery, 17(2), 114-122.

Kalyujna, L. D., Grechanska, L. V., \& Petrenko, A. V. (2014). Rol’ rozsmoktuvalnoi terapii v likuvanni hvoryh na acne [The role of resorptive therapy for treatment of acne patients]. Klinichna Imunologiya. Alergologiya. Infektologiya, (8), 41-44 (in Ukrainian).

Kang, S. S., Kauls, L. S., \& Gaspari, A. A. (2006). Toll-like receptors: Applications to dermatologic disease. Journal of the American Academy of Dermatology, 54(6), 951-983.

Klasen, S., Hammermann, R., Fuhrmann, M., Lindemann, D., Beck, K. F., Pfeilschifter, J., \& Racké, K. (2001). Glucocorticoids inhibit lipopolysaccharide-induced up-regulation of arginase in rat alveolar macrophages. British Journal of Pharmacology, 132(6), 1349-1357.

Korolenko, V. V. (2016). Perspektyvni imunni mehanizmy likuvannja pacijentiv $\mathrm{z}$ akne [Perspective immune mechanisms of treatment of patients with acne]. Ukrainian Journal of Dermatology, Venereology, Cosmetology, 4, 79-81 (in Ukrainian).

Krysko, D. V., Berghe, T. V., Parthoens, E., D’Herde, K., \& Vandenabeele, P. (2008). Methods for distinguishing apoptotic from necrotic cells and measuring their clearance. Methods in Enzymology, 442, 307-341.

Lai, Y., \& Gallo, R. L. (2008). Toll-like receptors in skin infections and inflammatory diseases. Infectious Disorders-Drug Targets, 8(3), 144-155.

Lavryk, G., Korniychuk, O., \& Tymkiv, M. (2017). Ultrastructural changes in biofilm forms of staphylococci cultivated in a mixed culture with lactobacilli. Regulatory Mechanisms in Biosystems, 8(1), 98-103.

Lugovskoy, S. P. (2002). Zminy aktyvnosti fermentnogo spektra limfocytiv peryferijnoi’ krovi pry svyncevij intoksykacii' (cytohimichne doslidzhennja) [Changes in the activity of the enzyme spectrum of peripheral blood lymphocytes upon lead intoxication (cytochemical study)]. Laboratorna Diagnostyka, (2), 29-32 (in Ukrainian).

Mempel, M., Voelcker, V., Köllisch, G., Plank, C., Rad, R., Gerhard, M., Schnopp, C., Fraunberger, P., Walli, A. K., Ring, J., Abeck, D., \& Ollert, M. (2003). Toll-like receptor expression in human keratinocytes: Nuclear factor $\kappa \mathrm{B}$ controlled gene activation by Staphylococcus aureus is Toll-like receptor 2 but not Toll-like receptor 4 or platelet activating factor receptor dependent. Journal of Investigative Dermatology, 121(6), 1389-1396.

Miller, L. S. (2008). Toll-like receptors in skin. Advances in Dermatology, 24, 71-87.

Miragaia, M., de Lencastre, H., Perdreau-Remington, F., Chambers, H. F., Higashi, J., Sullam, P. M., Lin, J., Wong, K. I., King, K. A., Otto, M., Sensabaugh, G. F., \& Diep, B. A. (2009). Genetic diversity of arginine catabolic mobile element in Staphylococcus epidermidis. PloS One, 4(11), e7722.

Monakhov, S. A., \& Ivanov, O. L. (2012). Akne. Etiopatogenez, klinika, terapiya [Acne. Etiopatogenez, clinic, therapy]. Bayer HealthCare, Moscow (in Russian).

Munder, M., Mollinedo, F., Calafat, J., Canchado, J., Gil-Lamaignere, C., Fuentes, J. M., \& Müller, F. M. (2005). Arginase I is constitutively expressed in human granulocytes and participates in fungicidal activity. Blood, 105(6), 2549-2556.

Myadelets, O. D., \& Adaskevich, V. P. (2006). Morfofunktcionalnaja dermatology [Morpho-functional dermatology]. Medicinskaja Literatura, Moscow (in Russian). 
Nagao, K., \& Segre, J. A. (2015). “Bringing up baby” to tolerate germs. Immunity, 43(5), 842-844.

Nakamura, Y., Oscherwitz, J., Cease, K. B., Chan, S. M., Mucoz-Planill, R., Hasegawa, M., Villaruz, A. E., Cheung, G.-Y. C., McGavin, M. J., Travers, J. B., Otto, M., Inohara, N., \& Núñez, G. (2013). Staphylococcus (dgr)-toxin induces allergic skin disease by activating mast cells. Nature, 503(7476), $397-401$.

Numata, S., Akamatsu, H., Akaza, N., Yagami, A., Nakata, S., \& Matsunaga, K. (2014). Analysis of facial skin-resident microbiota in Japanese acne patients. Dermatology, 228(1), 86-92.

Ochoa, A. C., Zea, A. H., Hernandez, C., \& Rodriguez, P. C. (2007). Arginase, prostaglandins, and myeloid-derived suppressor cells in renal cell carcinoma. Clinical Cancer Research, 13(2), 721s-726s.

Otto, M. (2009). Staphylococcus epidermidis - the accidental pathogen. Nature Reviews Microbiology, 7(8), 555-567.

Otto, M. (2010). Basis of virulence in community-associated methicillin-resistant Staphylococcus aureus. Annual Review of Microbiology, 64, 143-162.

Peral, M. C., Huaman Martinez, M. A., \& Valdez, J. C. (2009). Bacteriotherapy with Lactobacillus plantarum in burns. International Wound Journal, 6(1), 73-81.

Peral, M. C., Rachid, M. M., Gobbato, N. M., Martinez, M. H., \& Valdez, J. C. (2010). Interleukin-8 production by polymorphonuclear leukocytes from patients with chronic infected leg ulcers treated with Lactobacillus plantarum. Clinical Microbiology and Infection, 16(3), 281-286.

Peretiatko, Y. V., \& Sybirna, N. O. (2009). Osoblyvosti arginaznogo ta NOsyntaznogo shljahiv metabolizmu L-argininu v lejkocytah peryferychnoi' krovi shhuriv za hronichnogo rentgenivs'kogo oprominennja [Particularities of arginase and NO-synthase pathways of L-arginine conversion in the leucocytes of peripheral blood under the X-ray radiation]. Ukrai'ns'kyj Biohimichnyj Zhumal, 81(2), 40-48 (in Ukrainian).

Prince, T., McBain, A. J., \& O’Neill, C. A. (2012). Lactobacillus reuteri protects epidermal keratinocytes from Staphylococcus aureus-induced cell death by competitive exclusion. Applied and Environmental Microbiology, 78(15), 5119-5126.

Protsenko, T. V., Protsenko, O. A., Buturlinova, A. S., \& Lukyanchenko, E. N. (2015). Innovacionnye aspekty $\mathrm{v}$ patogeneze i terapii akne [Innovative aspects in the pathogenesis and therapy of acne]. Ukrainian Journal of Dermatology, Venereology, Cosmetology, (4), 79-81 (in Ukrainian).

Sanford, J. A., \& Gallo, R. L. (2013). Functions of the skin microbiota in health and disease. Seminars in Immunology, 25(5), 370-377.
Scharschmidt, T. C., \& Fischbach, M. A. (2013). What lives on our skin: Ecology, genomics and therapeutic opportunities of the skin microbiome. Drug Discovery Today: Disease Mechanisms, 10(3), e83-e89.

Schlegel, K., \& Füllekrug, M. (2002). 50 years of schumann resonance. Physik in Unserer Zeit, 33(6), 256-264.

Sorokina, E. V. (2012). Toll-podobnye receptory i pervichnoe raspoznavanie patogena pri dermatozah infekcionnoj i neinfekcionnoj jetiologii [Toll-like receptors and primary pathogen recognition in infectious and non-infectious cutaneous pathology]. Immunopatologija, Allergologija, Infektologija, 2, 615 (in Russian).

Valdez, J. C., Peral, M. C., Rachid, M., Santana, M., \& Perdigon, G. (2005). Interference of Lactobacillus plantarum with Pseudomonas aeruginosa in vitro and in infected burns: The potential use of probiotics in wound treatment. Clinical Microbiology and Infection, 11(6), 472-479.

Valins, W., Amini, S., \& Berman, B. (2010). The expression of Toll-like receptors in dermatological diseases and the therapeutic effect of current and newer topical Toll-like receptor modulators. The Journal of Clinical and Aesthetic Dermatology, 3(9), 20-29.

Volkova, L. A., Khalifa, I. L., \& Kabanova, I. N. (2001). Impact of the impaired intestinal microflora on the course of acne vulgaris. Klinicheskaia Meditsina, 79(6), 39-41.

Vos, P., Garrity, G., Jones, D., Krieg, N. R., Ludwig, W., Rainey, F. A., Schleifer, K.-H., \& Whitman, W. (Eds.). (2009). Bergey’s Manual of Systematic Bacteriology. Vol. 3: The Firmicutes. Springer.

Williams, H. C., Dellavalle, R. P., \& Garner, S. (2012). Acne vulgaris. The Lancet, 379(9813), 361-372.

Yakubets, O. I., Fafula, R. V., Vorobets, D. Z., \& Vorobets, Z. D. (2013). Osoblyvosti arginaznogo ta NO-syntaznogo shljahiv metabolizmu L-argininu v limfocytah peryferychnoi’ krovi hvoryh na rak jajechnyka [Peculiarities of arginase and no-synthase pathways of l-arginine metabolism in peripheral blood lymphocytes of patients with ovarian cancer]. Ukrai'ns'kyj Biohimichnyj Zhurnal, 85(5), 105-113 (in Ukrainian).

Yoshimoto, T., Takeda, K., Tanaka, T., Ohkusu, K., Kashiwamura, S. I., Okamura, H., Akira, S., \& Nakanishi, K. (1998). IL-12 up-regulates IL-18 receptor expression on T cells, Th1 cells, and B cells: Synergism with IL-18 for IFN- $\gamma$ production. The Journal of Immunology, 161(7), 3400-3407.

Zouboulis, C. C. (2009). Propionibacterium acnes and sebaceous lipogenesis: A love-hate relationship? Journal of Investigative Dermatology, 129(9), 2093-2096. 